\title{
ZAGADNIENIE PLAGIATU LITERACKIEGO, CZYLI \\ O DOMNIEMANIU WINY/NIEWINNOŚCI TŁUMACZA SŁÓW PARĘ
}

Zarys treści: Niniejszy artykuł porusza zagadnienie plagiatu w aspekcie przekładu tekstów literackich, tj. słuszności podstaw do wydawania sądów o ewentualnych plagiatach uwarunkowań prawnych regulujących kwestie ochrony praw autorskich w tym zakresie oraz tego, w jaki sposób należy interpretować treść tych zapisów w kontekście przekładów tekstów izosemiotycznych.

Jeżeli okradasz jednego autora, jest to plagiat. Jeżeli okradasz dwóch, jest to już prowadzenie badań.

Wilson Mizner - amerykański scenarzysta

Niniejszy artykuł dedykuję Pani Profesor Jadwidze Koniecznej-Twardzikowej, za obudzenie we mnie potrzeby badania przekładu jako dzieła oryginalnego

\section{Wstęp}

yśląc o dokonywaniu przekładu tekstu z języka A na język B, nie sposób oprzeć się wrażeniu, że język - jako twór żywy społecznie - dostarcza swoim użytkownikom praktycznie nieograniczonej, przez zabiegi syntaktyczne, ilości językowych sposobów wyrażania myśli i opinii omawiających 
rzeczywistość pozajęzykową. W praktyce społeczna czy - jak postulują socjologowie - uspołeczniająca funkcja języka nie może wykraczać swoją egzystencją poza społeczne normy ludzkiej komunikacji; normy społeczne obejmują swoim działaniem także sferę języka, a oparta na tych pierwszych kognitywna teoria komunikacji dostarcza nam podstaw do rozważań nad interpretacyjno-tłumaczeniowym schematyzowaniem językowych zachowań człowieka, co ma bezpośrednie przełożenie na głębszą dyskusję nad zagadnieniem plagiatu w przekładzie. Niniejszy artykuł jest próbą skonfrontowania założeń leżących u podstaw tworzenia przepisów legislacyjnych dotyczących ochrony praw autorskich praktyką tłumaczeniową $\mathrm{w}$ aspekcie wielokrotnego przekładania na język polski tych samych dzieł literatury światowej oraz zbadania, czy ewentualne podobieństwa pomiędzy obiema wersjami przekładu mogą świadczyć o ewentualnym popełnieniu plagiatu przez jednego $\mathrm{z}$ autorów tekstu docelowego (TD). Co istotne, konfrontowane przekłady w części praktycznej stanowią tylko materiał poglądowy do dyskusji i mają charakter wyłącznie polemiczny, konieczny do dalszych teoretycznych dywagacji nad zagadnieniem łamania praw autorskich w aspekcie praktyki tłumaczeniowej.

\section{Socjologiczne uwarunkowania komunikacji językowej}

Aby w pełni oddać założenia teoretyczne leżące u podstaw wysuwanych zarzutów o dokonanie plagiatu w ujęciu prawnym (nie prawniczym), konieczne jest sięgnięcie głębiej w strukturę wyuczonych językowych zachowań człowieka żyjącego w ramach określonego środowiska (patrz: określona grupa użytkowników wspólnego języka narodowego), użytkowników tego języka, z jakim się utożsamiają i z jakimi przez innych są utożsamiani. Myślę tu o analizie komunikacji językowej przez pryzmat socjologii języka, którą J.K. Chambers (1995: 7-11) widzi jako „badanie związków pomiędzy językiem a społecznością w celu zrozumienia struktury społecznej jego użytkowników"'. Sapirowskie (1921: 25) podejście do języka jako elementu solidaryzującego społeczności, które nim się posługują, wyznacza granice nie tylko zakresu występowania danego języka narodowego, ale także zakresu tożsamości socjolingwistycznej jego użytkowników, których kognitywny świat komunikacji językowej może być odmienny od użytkowników innego języka narodowego.

${ }^{1}$ Wszystkie polskie przekłady literatury obcojęzycznej, jeżeli nie zaznaczono inaczej - 


\section{Język narodowy i jego granice w przestrzeni kognitywnej}

Język to nie zjawisko społeczne, ani także nie naturalna czynność wykonywana przez nasze fizyczne jestestwo - ludzkie ciało, a zdolność komunikowania się przy pomocy języka nie jest mechaniczna. Język jest nie-narzędziem, niczym naszym kolejnym organem (Gadamer [1966] 2001: 52).

Zdobycze psychologii poznawczej, której podwaliny stanowią dzisiaj także podstawę rozwoju językoznawstwa kognitywnego, to opracowanie teorii schematów poznawczych, pozwalających wyjaśniać zależność zachowań komunikacyjnych użytkowników języka, złączonych m.in. takim wspólnym mianownikiem jak jednolite pochodzenie etniczne czy też narodowe. Język, którego używamy, nie opisuje otaczającej nas rzeczywistości, lecz jedynie sposób, w jaki ją postrzegamy w chwili mówienia, użycia języka. „Wartość językoznawstwa kognitywnego nie polega na dokonywaniu odkryć co do prawdziwej natury języka (ani języków), lecz na możliwości usystematyzowania od dawna znanych, empirycznie sprawdzonych intuicji" (Tabakowska [1993] 2001: 100). Podstawą tworzenia pojęć, które schematyzują nasze wyobrażenie o świecie, są schematy wyobrażeniowe (ang. image schemas) (por. Tabakowska [1993] 2001:39-40). To właśnie one tworzą wspólną kognitywną platformę kształtowania języka jako zwierciadła obrazu świata fizykalnego. „Z jednej strony można mówić o znaczeniu tekstu, a więc o tekstowej reprezentacji semantycznej, z drugiej - o znaczeniu zdarzenia, o którym jest tekst, a więc o reprezentacji określonego fragmentu rzeczywistości pozajęzykowej, do której tekst 'odsyłał”' (Duszak 1998: 249-250). Zatem czytelność paraleli między znaczącym elementem języka a składnikiem rzeczywistości pozajęzykowej, którą ten pierwszy opisuje bądź przedstawia, daje współużytkownikom jednego zwierzchniego języka narodowego, utożsamianego $\mathrm{z}$ daną kulturą, możliwość hipotetycznie bezbłędnego i seryjnie powtarzalnego odczytywania znaczenia treści zawartej w przesyłanym komunikacie tekstowym. W taki sposób można zdefiniować świadomość językową warunkującą równomierny socjologicznie rozwój języka w jednolitym kompleksie kulturowym, np. amerykańskim czy polskim, którego członkowie są nośnikiem jej cech charakterystycznych także z ujęcia socjolingwistycznego (np. upodobanie młodych Afroamerykanów do alternacji amerykańskiej angielszczyzny w zakresie pisowni czy intencjonalnie innej wymowy słownictwa standardowego jako slangowego). 


\section{Świadomość językowa - zalążek seryjności formułowania komunikatów językowych}

Całość wspólnych doświadczeń jednej społeczności językowej na poziomie zwierzchnim, w ramach piramidy komunikacyjnej - czyli na poziomie narodowym (przy użyciu wszystkich rejestrów języka, począwszy od formalnego, a na slangu skończywszy) - jest gromadzona w swoistym kognitywnym „koszu” wspólnych przeżyć, czy raczej doświadczeń kulturowo-komunikacyjnych, które kształtują komplementarną świadomość językową, a w efekcie intrakulturową komunikację w rozumieniu socjolingwistycznym. Na świadomość językową składa się cała nasza wiedza o otaczającym nas świecie oraz możliwości jego opisywania. Podobnie jak w przypadku komunikacji interkulturowej, także w tym przypadku użytkownik języka uruchamia mechanizm komunikacyjny, na który składają się cztery typy kompetencji komunikacyjnych, szczegółowo opisanych przez Pisarską i Tomaszkiewicz (1996: 66-71), a niezbędnych dla właściwego zrozumienia komunikatu tekstowego. Są to: kompetencja językowa, encyklopedyczna, logiczna oraz pragmatyczno-retoryczna. Szczególnie kompetencja encyklopedyczna, czyli „cały bagaż wiedzy i informacji, którymi dysponuje tłumacz [ale także każdy użytkownik języka - M.G.] i dotyczy nie tylko kontekstu, ale także wierzeń, systemów reprezentacji, ocen i interpretacji rzeczywistości” (ibidem), składa się na bagaż kognitywny, którego częścią w pryzmacie socjolingwistycznym jest właśnie świadomość językowa.

To dzięki świadomości językowej kształtującej w miarę trwałą wspólnotę komunikacyjną można mówić o prowadzeniu badań w ujęciu pragmatycznym. Pragmatyczne studia nad komunikacją interpersonalną (por. Austin 1962: 18-24) dotyczyły intencji komunikacyjnych nadawców komunikatów oraz reakcji ich odbiorców. Teoria aktów mowy (ang. speech acts) ujmuje poszczególne komunikaty zawsze w ich ścisłym związku z sytuacją, w której zostały do życia powołane, aby możliwe było zbadanie siły perlokucyjnej owych komunikatów. Komunikacja w ujęciu pragmatycznym opiera się głównie na wymianie informacji, która ujawnia intencje komunikacyjne nadawcy komunikatu, dzięki czemu, badając potencjał komunikacyjny poszczególnych wypowiedzeń ponad poziomem znaczeniowym, można ustalić relacje łączące uczestników samego aktu komunikacyjnego. Takie relacje to wspólna platforma komunikacyjna, ułatwiająca komunikację językową poprzez wypracowanie jednolitych modeli komunikacyjnych upraszczających i ekonomizujących proces nadawania i odbierania komunikatu tekstowego; dzięki temu możemy mówić o studiach nad relewancją językową (por. Sperber i Wilson [1986] 1995). Wypracowanie wspólnych dla danej społeczności językowej mode- 
li komunikacyjnych, czyli ich useryjnienie najpierw na poziomie tworzenia schematów wyobrażeniowych, a następnie na poziomie ich językowej ekspresji, doprowadza w praktyce do powstawania podobnych, jeżeli nie zbieżnych na poziomie syntaktycznym, komunikatów tekstowych, generowanych przez dwóch odmiennych użytkowników tego samego języka, zakotwiczonych w tym samym kręgu kulturowym języka.

Jak zatem w aspekcie wyprowadzonej powyżej teorii przypadkowej seryjności powoływania do życia podobnych komunikatów tekstowych w ujęciu atomistycznej analizy tekstu na jego płytkim poziomie rysuje się zasadność stawiania zarzutów o dokonanie plagiatu w przekładzie literackim, który mimo interlingwalnego charakteru pozostaje nadal komunikatem tekstowym?

\section{Prawo autorskie w ujęciu normatywnych aktów prawnych a pojęcie plagiatu}

Zarówno prawodawstwo polskie ${ }^{2}$, jak i europejskie ${ }^{3}$ dość precyzyjnie ujmuje w swych zapisach naturę i charakterystykę prawa autorskiego, jego zakres działania, a także czas jego obowiązywania w stosunku do przedmiotu, którego dotyczy. Walidacja któregokolwiek z zapisów kompletu tych przepisów regulujących, a określanych przez ustawodawcę jako naruszenie, jest przestępstwem, podobnie jak dokonanie plagiatu, także tłumaczeniowego.

Zapisy art. 1. ustawy O prawie autorskim i prawach pokrewnych mówią wyraźnie, że „przedmiotem prawa autorskiego jest każdy przejaw działalności twórczej o indywidualnym charakterze, ustalony w jakiejkolwiek postaci, niezależnie od wartości, przeznaczenia i sposobu wyrażania”. Wśród przedmiotów objętych prawem autorskim znajduje się także każdy przejaw działalności twórczej, zwany przez ustawodawcę „utworem”, a w szczególności utwory (art. 1.1):

- wyrażone słowem, symbolami matematycznymi, znakami graficznymi (literackie, publicystyczne, naukowe, kartograficzne oraz programy komputerowe),

${ }^{2}$ DzU $1994 \mathrm{Nr} 24$ poz. 83 z dnia 4 lutego 1994 r. O prawie autorskim i prawach pokrewnych.

${ }^{3}$ DzU Nr 3 poz. 11/12 Traktatu Światowej Organizacji Własności Intelektualnej o Prawie Autorskim, sporządzony w Genewie dnia 20 grudnia 1996 r. W imieniu Rzeczypospolitej Polskiej Prezydent Rzeczypospolitej Polskiej. 
- plastyczne,

- fotograficzne,

- lutnicze,

- wzornictwa przemysłowego,

- architektoniczne, architektoniczno-urbanistyczne i urbanistyczne,

- muzyczne i słowno-muzyczne,

- sceniczne, sceniczno-muzyczne, choreograficzne i pantomimiczne,

- audiowizualne (w tym wizualne i audialne).

Utwór jest przedmiotem prawa autorskiego od chwili ustalenia, chociażby miał postać nieukończoną. Ochrona przysługuje twórcy niezależnie od spełnienia jakichkolwiek formalności.

Plagiatem będzie użycie, powielanie czy rozpowszechnianie powyższych utworów bez zgody właściciela praw autorskich. Interesująca mnie z punktu widzenia niniejszej pracy domena plagiatu tłumaczeniowego również jest regulowana przez stosowne zapisy prawne. W myśl art. 2 ustawy o ochronie praw autorskich ${ }^{4}$ także „opracowanie cudzego utworu, w szczególności tłumaczenie, przeróbka, adaptacja, jest przedmiotem prawa autorskiego bez uszczerbku dla prawa do utworu pierwotnego". Wytyczne stworzone przez ustawodawców polskich jak i europejskich jasno precyzują, jak plagiat tłumaczeniowy jest charakteryzowany. Ustawodawca nie precyzuje, jakie przesłanki należy wziąć pod uwagę, by potwierdzić słuszność stawianych tez o dokonanie plagiatu przekładu tekstu literackiego, który jest przedmiotem niniejszego artykułu.

\section{Literacka powtarzalność zachowań artystycznych a plagiat}

Powtarzanie, kopiowanie czy naśladowanie to typowe społeczne zachowania człowieka, które mają także bezpośrednie przełożenie na zachowania językowe. Plagiat - skutek powyższych zachowań, jest pewnym skrótem myślowym, odnoszącym się do sytuacji naruszenia ustawy o ochronie praw autorskich.

${ }^{4}$ DzU 2006 Nr 90, poz. 631, Nr 94, poz. 658, Nr 121, poz. 843. Odnośnik nr 1 dodany do tytułu ustawy przez art. 12 ustawy z dnia 20 kwietnia 2004 r. o zmianie i uchyleniu niektórych ustaw w związku z uzyskaniem przez Rzeczpospolitą Polską członkostwa w Unii Europejskiej (DzU $\mathrm{Nr}$ 96, poz. 959), która weszła w życie z dniem 1 maja 2004 r. Niniejsza ustawa dokonuje w zakresie swojej regulacji wdrożenia następujących dyrektyw Wspólnot Europejskich. 
Wikipedia ${ }^{5}$ w następujący sposób wyjaśnia znaczenie terminu „plagiat”: „(łac. Plagium - kradzież) - skopiowanie cudzej pracy (lub jej części) i przedstawienie pod własnym nazwiskiem, np. odkrycia, piosenki, wiersza, wynalazku, pracy magisterskiej, pracy doktorskiej, publikacji naukowej”. Także wszelkie zamierzone wzorowanie się jednego tłumacza na pracy innego może nosić znamiona plagiatu.

Howard (1968: 32) jest zdania, że naturą postmodernizmu było podważanie teorii niezmienności, że język i znaczenie są stałe i stabilne. Fakt, że tekst można poddać zabiegowi dekonstrukcji, w zamyśle Derridy nie oznacza automatycznie, że znaczenie oryginału będzie zmienione w pierwszym, ale także w każdym kolejnym przekładzie tego oryginału. Jednakże znaczenie poszczególnych komunikatów tekstowych nie będzie zawsze wyrażane przez te same układy struktur gramatycznych czy stylistycznych języka, więc każdy kolejny przekład tego samego oryginału będzie charakteryzował się niepowtarzalnym „miernikiem indywidualności”; „Miernik indywidualności jest wynikiem pracy rutynowej szablonowej, czy też takim wynikiem, który jest jednym z możliwych do osiągnięcia przez osoby (specjalistów) podejmujących się tego samego zadania" (Barta i in. 1995: 49). Dzieło literackie to nie sztywne corpus mechanicum, ponieważ nie nosi ono znamion seryjności w procesie powstawania, czy raczej w procesie powoływania do życia. Także odtwarzanie cech konstrukcji sceny literackiego oryginału nie będzie sprowadzać się do zmechanizowanego odtwarzania treści tekstu początkowego (TP) w strukturze tekstowej przekładu i - co ważne w omawianym przeze mnie aspekcie odtwarzanie to nie będzie przyjmowało zawsze takiej samej seryjnej formy tekstowej. Dla Bowdena (1996: 2), Howarda (1993: 240-242), a także dla Scollona (1995: 18) plagiat to swoiste „uprowadzenie” (ang. kidnapping) treści jakiegoś określonego tekstu, przynależnego jednemu autorowi, które przybiera także formę naruszenia czy pogwałcenia prawa autorskiego. Inaczej tę samą kwestię widzi Posner (2002: 23); z dwóch powyższych przypadków, plagiator przynajmniej nie stara się udawać, że dzierży palmę pierwszeństwa w propagowaniu danej idei czy pomysłu poprzez przywłaszczenie sobie samego zamysłu twórczego. Plagiator kopiuje, zazwyczaj bezmyślnie, idee uprzednio ogłoszone przez innego twórcę. Osoba naruszająca prawa autorskie pragnie z tego faktu czerpać dodatkowe korzyści, a nie tylko podpisać się pod słowami czy czynami innej osoby. Jak zatem zastosować w praktyce teoretyczne rozważania na temat charakterystyki plagiatu w przekładzie literackim?

\footnotetext{
5 Por. http://pl.wikipedia.org/wiki/plagiat.
} 


\section{Badania komparatystyczne, czyli tropienie plagiatu literackiego a umocowanie w faktach}

W niniejszej części chciałbym omówić dwa korespondujące ze sobą polskie przekłady dwóch utworów literackich. Pierwszy z nich to tekst wierszowany: Hamlet W. Shakespeare’a w przekładzie M. Słomczyńskiego oraz S. Barańczaka, drugi to proza: Duma i uprzedzenie [Pride and Prejudice] J. Austin w przekładzie Anny Przedpełskiej-Trzeciakowskiej, a także Magdaleny Gawlik-Małkowskiej. Dokonując porównania każdego z polskich przekładów, wykażę, że w aspekcie przytoczonej powyżej teorii, słuszność stawiania zarzutów o dokonanie plagiatu literackiego może mieć podstawy tylko w ściśle określonej sytuacji.

\section{Analiza dwóch izosemiotycznych przekładów tekstów wierszowanych}

Analizie porównawczej poddałem dwa przypadkowo wybrane fragmenty dwóch najbardziej znanych polskich przekładów Hamleta W. Shakespeare’a, które dodatkowo cechuje odmienna długość poszczególnych kwestii dialogowych.

W tabeli 1 zestawiono zupełnie odmienne potraktowanie podmiotu logicznego drugiego zwrotu dialogowego w analizowanym przykładzie, który w dodatku nosi w języku angielskim cechy polisemiczne. O ile dla Słomczyńskiego man w obu zwrotach dialogowych może nieść odmienne znaczenie: odpowiednio „człowiek” oraz domyślnie „mężczyzna”, o tyle dla Barańczaka nawet implicytna polisemia nie jest tu zauważalna. Dodatkowo zaimki wskazujące ten, ta (niewystępujące w przekładzie Słomczyńskiego) powtarzane przez Barańczaka nie tylko nie mają swoich tekstowych znaczników w oryginale, ale mogą zostać uznane jako skłonność autora przekładu do nadtłumaczenia TP. W tej strategii celuje także Słomczyński, choć na innym poziomie. Fragment ten ujawnia, że jego przekład cechuje analiza głębi znaczeniowej oryginału w skali bardziej mikro niż makro - jak to jest u Barańczaka. Antyfeministyczna wymowa tego fragmentu poprzez żonglowanie wspomnianą już polisemicznością jest tu dobitnym przykładem nadtłumaczenia (por. Hellonger 2004: 63-70). 
Tabela 1

\begin{tabular}{|c|c|}
\hline \multicolumn{2}{|c|}{ Hamlet [Akt V, Scena 1] } \\
\hline \multicolumn{2}{|c|}{$\begin{array}{c}\text { Hamlet: What man dost thou dig it for? } \\
\text { Hamlet: What woman then? }\end{array}$} \\
\hline Tłum. Maciej Słomczyński, s. 143 & Tłum. Stanisław Barańczak, s. 174-175 \\
\hline $\begin{array}{l}\text { Hamlet: Dla jakiego człowieka to kopiesz? } \\
\text { Pierwszy grabarz: Dla żadnego, panie. } \\
\text { Hamlet: Dla jakiej więc kobiety? }\end{array}$ & $\begin{array}{l}\text { Hamlet: Dla kogo wykopałeś ten grób? } \\
\text { Kim jest ten zmarły? } \\
\text { Pierwszy grabarz: Żaden ,ten”. } \\
\text { Hamlet: A więc ,ta”? Kobieta? }\end{array}$ \\
\hline
\end{tabular}

Przypadkowe nadanie danemu tekstowi treści antykobiecych (a to za sprawą zmiany panujących mód oraz obyczajów bądź w wyniku mylnego zinterpretowania przez odbiorcę treści promowanych przez autora; intentio lectoris, a także intentio auctoris, idąc śladami Umberto Eco, 1984) jest wybaczalne. Niewybaczalne natomiast musi pozostać intencjonalne sformatowanie tekstu na modłę antyfeminizmu przez nasycenie go treściami bijącymi w godność kobiety, o czym szeroko pisze Tenesini (1999: 64-95).

Tabela 2 zawiera dłuższy ciąg tekstu, którego polskie przekłady znacznie różnią się między sobą. Pomijając konieczny podział na poszczególne zwroty dialogowe, treść każdego $\mathrm{z}$ nich $\mathrm{w}$ istotny sposób jest odmienna względem siebie $\mathrm{w}$ kilku powtarzających się elementach. Oryginalny zwrot While the grows każdy z tłumaczy przełożył odpowiednio na Nim trawa wzejdzie i Nim słońce wzejdzie, co jest wynikiem działań interpretatorskich tłumacza, gdyż sam oryginał pozostaje $w$ tym aspekcie niedomknięty, pozwalając tłumaczowi dać upust swym artystycznym zapędom. Podobnie znaczenie zawołania my lord jest rozumiane odmiennie przez obu tłumaczy. Dla Słomczyńskiego lord ma wymiar bardziej symboliczny, jako zwrot adresatywny pan (w domyśle władca), wyrażający linię zależności między poddanym a suwerenem. Barańczak ten sam przypadek traktuje inaczej - implikując, że czytelnik czytał wprowadzenie do dramatu, może śmiało nadinterpretować oryginał, dokonując wyraźnego nadtłumaczenia, stojącego jednocześnie w zgodzie z oryginalnymi założeniami konstrukcji sceny dokonanymi przez Shakespeare’a. Hamlet to faktycznie Książe Danii, o czym czytelnik wie, ale czego autor nie podkreśla w każdym ustępie. 
Tabela 2

\begin{tabular}{|c|c|}
\hline \multicolumn{2}{|c|}{ Hamlet [Akt III, Scena 2] } \\
\hline $\begin{array}{l}\text { Hamlet: AY, sir, but 'While the grows' - } \\
\text { the proverb is something musty. O, the } \\
\text { recorders, let me see one. To withdrawn } \\
\text { with you, why do you go about to reco- } \\
\text { ver the wind of me, as if you would dri- } \\
\text { ve me into a toil? } \\
\text { Guldernstern: } \mathrm{O} \text {, my lord, if my duty be } \\
\text { too bold, my love is too unmannerly. }\end{array}$ & $\begin{array}{l}H: \text { I do not well understand that - will you } \\
\quad \text { play upon this pipe? } \\
\text { G: } \text { My lord, I cannot. } \\
\text { H: I pray you. } \\
\text { G: Believe me, I cannot. } \\
\text { H: I do beseech you. } \\
\text { G: I know no touch of it, my lord. }\end{array}$ \\
\hline Tłum. 1 & Tłum. Stanisław Barańczak, s. 111-112 \\
\hline $\begin{array}{l}\text { H: Tak panie, lecz „Nim trawa wzej- } \\
\text { dzie”... - Nieco stęchłe to przysłowie. } \\
\text { - O, flety! Pokażcie no jeden - By już } \\
\text { zakończyć z tobą: - Czemu dążycie jak } \\
\text { nagonka za moim tropem, próbując go } \\
\text { zwietrzyć, jak gdybyście chcieli mnie } \\
\text { wpędzić na myśliwych? } \\
\text { G: O, panie mój, jeśli powinność moja jest } \\
\text { zbyt natarczywa, również i miłość moja } \\
\text { jest nieobyczajnie niepowściągliwa. } \\
\text { H: Nie pojmuję tego dobrze. Czy zechcesz } \\
\text { zagrać mi na tej fujarce? } \\
\text { G: Nie mogę, panie mój. } \\
\text { H: Proszę cię. } \\
\text { G: Nie umiem, uwierz mi. } \\
\text { H: Błagam cię. } \\
\text { G: Nie wiem, co z tym czynić, panie mój. }\end{array}$ & $\begin{array}{l}\text { H: Tak, ale „nim słońce wzejdzie”... - } \\
\text { znacie to zapleśniałe przysłowie? O, fle- } \\
\text { ty! Pokaż mi jeden. - Pozwólcie, że was } \\
\text { spytam na uboczu: czemu mnie tak za- } \\
\text { chodzicie pod wiatr, jak zwierzynę, } \\
\text { którą się wpędza w matnię? } \\
\text { G: Książę, jeśli przesadziłem w gorliwości, } \\
\text { to tylko dlatego, że moja przyjaźń nie } \\
\text { mieści się w granicach etykiety. } \\
\text { H: Nie bardzo rozumiem. Nie zagrałbyś na } \\
\text { tym flecie? } \\
\text { G: Nie umiem, książę. } \\
\text { H: Proszę cię, zagraj. } \\
\text { G: Naprawdę nie umiem. } \\
\text { H: Ale ja bardzo cię proszę. } \\
\text { G: Nie wiem nawet, jak się tym posługi- } \\
\text { wać. }\end{array}$ \\
\hline
\end{tabular}

Również styl jest odmienny dla obu przekładów. Słomczyński preferuje styl języka wymagający od czytelnika uwagi i wgłębienia się w ducha epoki. Styl Barańczaka jest bardziej uwspółcześniony (beseech jako prosić, a nie błagać, jak jest to u Słomczyńskiego), łatwiejszy w odbiorze jako „popularne dzieło literackie", a przez to sztuka chętniej jest wystawiana na deskach teatrów całej Polski. W suchej atomistycznej analizie oba przekłady różnią się między sobą liczbą sylab przypadających na poszczególne zwroty w monologu (na korzyść Słomczyńskiego - zbliżonego rozpiętością dramatu scenicznego do oryginału), choć ich chronologiczność jest względem 
oryginału jednakowa. Zdaniem Portera (1993: 71-72) podobieństwo kilku przekładów tekstów tego typu jest nieuniknione, ponieważ zamknięte ramy tekstowe, które ja - powołując się na Mocarz (2002: 124) - określam mianem jednostek tłumaczenia - narzucają tłumaczowi z góry określony sposób formowania TD na modłę oryginału. Poszczególne zwroty dialogowe tekstu wierszowanego to nic innego jak właśnie jednostki tłumaczenia identyfikowane w tekście wyjściowym jednostki sensu, które z uwagi na relewantne znaczenie mają swój tekstowy odpowiednik w tekście docelowym (ibidem).

Zatem w myśl rozważań teoretycznych z rozdziału 2 można wskazać jedynie na podobieństwa czy konieczne zbieżności między oboma przekładami, ale nigdy w myśl zapisów prawnych jeden przekład nie będzie plagiatem drugiego, gdyż zarówno ideologicznie, jak i tekstowo oba dzieła są względem siebie odmienne. Upraszczając, przekład Słomczyńskiego „egzotyzuje” oryginał (niem. Verfremdung) ${ }^{6}$, a Barańczak bardziej „naturalizuje” czy „urodzimia” (niem. Einbürgerung) go w swoim przekładzie, czyniąc łatwiejszym do odbioru w czasach współczesnych.

\section{Analiza dwóch izosemiotycznych przekładów tekstów niewierszowanych}

Literacka proza zarówno w aspekcie formalnej tekstowości oryginału, jak i formy, którą zyskuje ona w TD, odbiega w sposób zasadniczy od tekstów literackich wierszowanych. Przy takim tłumaczeniu zbieżność dwóch przekładów $\mathrm{w}$ aspekcie ich podobieństwa wydaje się mniej przypadkowa, jako że ramy podziału TP na poszczególne zwroty dialogowe nie muszą być tak restrykcyjnie przestrzegane w TD. Daje to tłumaczowi możność interpretacyjnego traktowania jednostki tłumaczenia jako jednostkowego komunikatu tekstowego poddawanego operacji przekładu; w ten sposób mogą powstawać nie tyle pełne przekłady, co adaptacje TP.

Tabele 3, 4 oraz 5 zawierają fragmenty tekstu powieści J. Austin Duma i uprzedzenie [Pride and Prejudice], będącego już literackim tekstem nie-wierszowanym.

${ }^{6}$ Koncepcje „egzotyzacji” (niem. Verfremdung) oraz „urodzimienia” (niem. Einbrügerung) tekstu poddawanego procesowi przekładu wprowadził Schleiermacher ([1813] 1973), choć dopiero Venuti (1995: 7-15) szerzej rozpropagował ten nurt filozoficzny wśród teoretyków przekładu. 
Tabela 3

\begin{tabular}{|c|c|}
\hline \multicolumn{2}{|c|}{ Pride and Prejudice [XVI, s. 81] } \\
\hline \multicolumn{2}{|c|}{$\begin{array}{l}\text { "I should take him, even on my slight acquaintance to be an ill-tempered man." Whic- } \\
\text { kham only shook his head. } \\
\text { "I wonder," said he, at the next opportunity of speaking, "whatever he is likely to be in } \\
\text { this country much longer." } \\
\text { "I do not at all know; but I heard nothing of his going away when I was at Netherfield." }\end{array}$} \\
\hline $\begin{array}{l}\text { Tłum. Anna Przedpełska-Trzeciakowska, } \\
\text { s. } 88\end{array}$ & $\begin{array}{l}\text { Tłum. Magdalena Gawlik-Małkowska, } \\
\text { s. 94-95 }\end{array}$ \\
\hline $\begin{array}{l}\text { Nawet moja krótka znajomość wystarczy, } \\
\text { bym go uważała za człowieka o przykrym } \\
\text { usposobieniu. } \\
\text { Wickham tylko potrząsnął głową. } \\
\text { - Ciekaw jestem - powiedział przy na- } \\
\text { stępnej sposobności - jak długo jeszcze } \\
\text { on tu chce zostać. } \\
\text { - Nic o tym nie wiadomo, ale kiedy by- } \\
\text { łam w Netherfield, nie słyszałam, by miał } \\
\text { wyjeżdżać. }\end{array}$ & $\begin{array}{l}\text { - Znam go dopiero od niedawna, ale uwa- } \\
\text { żam, że jego maniery pozostawiają wiele } \\
\text { do życzenia. } \\
\text { Wickham tylko potrząsnął głową. } \\
\text { - Ciekaw jestem - powiedział, ponownie } \\
\text { mogąc zabrać głos - jak długo jeszcze tu- } \\
\text { taj zabawi. } \\
\text { - Nie mam pojęcia. Podczas pobytu } \\
\text { w Netherfield nie słyszałem nic o jego pla- } \\
\text { nowanym wyjeździe. }\end{array}$ \\
\hline
\end{tabular}

Dwa opisane przekłady trzech dowolnie wybranych fragmentów całej powieści oddają w sposób komplementarny charakter i specyfikę realizowania przekładów przez samych ich twórców. Już na pierwszy rzut oka zauważalna jest odmienność w odwzorowywaniu natury stylu TP przez obie tłumaczki. Jak nakazuje komunikacyjna teoria przekładu (oparta na teorii relewancji tłumaczeniowej, por. Gutt 2000), analiza przekładu nie ma na celu dokonania porównania oryginału z przekładem, lecz interpretacji obu językowych wersji tekstu w generujących je środowiskach kognitywnych, jako że sumy eksplikatur i implikatur w oryginale jak i w przekładzie muszą być równe (Gutt 2000: 99). Podobnie styl TD powinien być zgodny z narracyjną koncepcją oryginału, wzbudzając $\mathrm{w}$ jego odbiorcy takie same albo zbliżone wrażenia i odczucia, jakie towarzyszyłyby czytelnikowi oryginału. Moim zdaniem styl przekładu Przedpełskiej-Trzeciakowskiej znacznie bardziej oddaje narratologiczną formę konstrukcji sceny samego oryginału (w ujęciu założeń szkoły literatury formalnej - por. Giles 1986: 70-72) w porównaniu z przekładem Gawlik-Małkowskiej. Oryginalny zwrot ill-tempered man Przedpełska-Trzeciakowska przetłumaczyła na człowiek o przykrym usposobieniu. Takie tłumaczenie znacznie pełniej oddaje specyfikę języka i klimat wiktoriańskiej Anglii 
niż fraza opisowa jego maniery pozostawiaja wiele do życzenia, którą posłużyła się Gawlik-Małkowska. Podobnie dwie inne frazy I do not at all know, a także at the next opportunity of speaking tłumaczki przełożyły odpowiednio na nic o tym nie wiadomo (P-T); nie mam pojęcia (G-M) oraz powiedział przy następnej sposobności (P-T); ponownie mogąc zabrać głos (G-M). Przedpełska-Trzeciakowska $\mathrm{w}$ całym swoim przekładzie stosuje $\mathrm{z}$ dużym powodzeniem „technikę wyszukiwania najbliższego synonimu”, która polega na zaproponowaniu najpełniejszego znaczeniowo synonimu dla elementu oryginału, który spełni w tym samym mikrokontekście funkcje komunikacyjne najbliższe ekwiwalentowi absolutnemu, jeżeli taki w ogóle istnieje (por. Garcarz 2007: 190). Dzięki takiemu zabiegowi przekład nie jest, jak ma to miejsce w wersji Gawlik-Małkowskiej, nacechowany rejestrem potocznym języka TD, który skutkuje zauważalnym uwspółcześnieniem oryginału. Takie niedopatrzenie zdradza obecność tłumacza, która nie powinna być dla czytelnika wyczuwalna.

Poza przypadkową zbieżnością w użyciu w obu przekładach tych samych leksemów natrafiłem na nieliczne miejsca, w których obie tłumaczki sformułowały w taki sam sposób Whickham only shook his head P-T/G-M: Wickham tylko potrząsnąt głową. Jednakże taka incydentalna zbieżność nie jest żadną podstawą do wysuwania wniosków o ewentualnym wzorowaniu się jednego tłumacza na pracy już znanej, jako że wspólna świadomość językowa obu tłumaczek reprezentujących wspólne środowisko kulturowe tego samego języka narodowego narzuca podobne modele zachowań komunikacyjnych wszystkim ludziom ją posiadającym. W tym przypadku będzie to świadomość językowa polska.

\section{Tabela 4}

\begin{tabular}{|l|l|}
\hline \multicolumn{2}{|c|}{ Pride and Prejudice [LIV s. 307] } \\
\hline \multicolumn{2}{|c|}{ "Yes, very indifferent indeed," said Elizabeth, laughingly. “Oh, Jane, take care." } \\
\hline $\begin{array}{l}\text { Tłum. Anna Przedpełska-Trzeciakowska, } \\
\text { s. } 389\end{array}$ & $\begin{array}{l}\text { Tłum. Magdalena Gawlik-Małkowska, } \\
\text { s. } 346\end{array}$ \\
\hline $\begin{array}{l}\text { - O tak, najzwyklejsza - odparła ze śmie- } \\
\text { chem Elizabeth. - Uważaj, Jane. }\end{array}$ & $\begin{array}{l}\text { - O tak, najzupełniej sobie obojętni - ro- } \\
\text { ześmiała się Elżbieta. - Jasne, siostrzycz- } \\
\text { ko, uważaj! }\end{array}$ \\
\hline
\end{tabular}


Tabela 5

Pride and Prejudice [XXXII, s. 171]

She had once or twice suggested to Elizabeth the possibility of his being partial to her, but Elizabeth always laughed at the idea.

Tłum. Anna Przedpełska-Trzeciakowska, $\quad$ Tłum. Magdalena Gawlik-Małkowska, s. 190 s. 213

Raz czy dwa razy podsunęła Elżbiecie myśl, że pan Darcy jest nią zainteresowany, przyjaciółka jednak śmiała się z tych Kilkakrotnie Charlotte dała przyjaciółce do zrozumienia, że nie jest mu obojętna, ale Elizabeth zbywała ją śmiechem. przypuszczeń.

Także konsekwencja w stosowaniu przyjętych rozwiązań systemowych w dokonywaniu przekładu danego tekstu jest specyficznym znacznikiem każdego pojedynczego TD. W porównywanych przeze mnie dwóch przekładach obie tłumaczki dokonały rozhermetyzowania TD w aspekcie stosowania jednolitego tłumaczenia nazw własnych (tablele 4,5 ) - w tym przypadku imion. Niekonsekwencja w tłumaczeniu oryginalnego Elizabeth wymiennie na ekwiwalent funkcjonalny Elżbieta i na zapożyczenie Elizabeth przez obie tłumaczki jest licznie zauważalna w różnych miejscach w obu tekstach. Alternacje tego typu bardzo często pojawiają się w przekładach tekstów literackich, $\mathrm{z}$ taką różnicą, że jeden tłumacz preferuje np. latinizację w tłumaczeniu nazw własnych, a inny np. zastosowanie naturalnych ekwiwalentów dla języka TD.

Znana jest ogólna tendencja do konsultowania się tłumaczy $\mathrm{z}$ istniejącymi już przekładami tekstów na nowo opracowywanych. Haynes-Burton (1995: 85-87) jest zdania, że tłumacze motywują się wzajemnie w celu osiągania, z każdym kolejnym tłumaczeniem, TD bliższego oryginałowi od strony poznawczej. Takie zabiegi nie są podstawą do wysuwania wniosku, że mogło dojść do dokonania plagiatu myśli twórczej innego autora-tłumacza, jeżeli nie zostały skopiowane całe partie innego tekstu, a oryginał (w tym przypadku dzieło literackie) nie pozostawia tłumaczowi pełnej swobody w doborze językowych środków artystycznego wyrazu.

\section{Wnioski}

Z jednej strony Barty i in. (1995: 49) twierdzą, że: „przesłanka oryginalności utworu zrealizowana jest wówczas, gdy istnieje subiektywnie nowy wytwór intelektu; jest ona zatem ujmowana wyłącznie w płaszczyźnie nowości 
subiektywnej i zorientowana retrospektywnie”. Z drugiej strony Błeszyński i Staszków (1983: 47) są zdania, że: „o plagiacie będzie decydowało wykazanie, że doszło do przywłaszczenia oryginalnych elementów cudzego dzieła, choćby nawet zostały one wplecione w odrębną nawet i oryginalną całość stworzoną przez plagiatora”. Moim zdaniem popełnienie plagiatu można ustalić, prowadząc ewidencję poszczególnych przekładów, porównując bliskie podobieństwa czy identyczności w budowie nie tyle fraz czy wyrazów, ale całych paragrafów. Dwóch użytkowników tego samego języka w sposób zbieżny formułuje swoje myśli i je wyraża. Teza postawiona w tytule artykułu jest dość przewrotna - zbieżność $\mathrm{w}$ widzeniu i opisywaniu tego samego świata przez dwóch różnych tłumaczy może pomóc w stworzeniu TD bliższego oryginałowi pod każdym komunikacyjnym aspektem. Sądzę zatem, że słuszność domniemywania dokonania plagiatu tłumaczeniowego ma umocowanie $\mathrm{w}$ faktach tylko $\mathrm{w}$ ściśle określonym przypadku, kiedy dwa różne przekłady zawierają całe jednolite bloki tego samego tekstu. W opinii Mallona (1989: 75) to nie kradzież tekstu, a samej jego treści jest „zbrodnią” cięższą, bo dokonywaną na istocie oryginału. Niekiedy jednak, jak uczy historia, plagiator pozostaje sławniejszy niż autor oryginału. W 1909 r. Guglielmo Marconi został laureatem Nagrody Nobla z dziedziny fizyki za wkład w rozwój telegrafii bezprzewodowej. Wcześniej, w latach 1895-1897, pracował nad skonstruowaniem radia, a 2 czerwca 1897 r. jako pierwszy uzyskał na nie patent, na kilka dni przed Nikolą Teslą. Ten fakt na zawsze przeszedł do historii świata. Niewiele ludzi zdaje sobie jednak sprawę, że Marconi przywłaszczył sobie odkrycie autorstwa Nikoli Tesli - serbskiego wynalazcy, poety i malarza, autora takich patentów, jak silnik elektryczny, prądnica prądu przemiennego, autotransformator, dynamo rowerowe, elektrownia wodna, bateria słoneczna, transformator czy świetlówka. Dopiero w 1943 r. świat poznał prawdę, kiedy to Sąd Najwyższy USA ogłosił, że patent zgłoszony przez Marconiego był plagiatem pomysłu Tesli. Wyrok ten nie zmienia jednak faktu, że w ogólnej świadomości ludzi na całym świecie to właśnie Marconi jest uważany na odkrywcę radia. Świadczyć o tym może liczba linków w przeglądarce internetowej google [www.google.com] zawierających zbitki słów „marconi radio” (29 700) oraz „tesla radio” (649).

Przekład artystyczny zawsze narażony jest na zarzut plagiatu, czy dotyczy on tylko części, czy całości pracy. Póki nie zostaną sprecyzowane przepisy ustawy o ochronie praw autorskich, co do stosowania określonych procedur sprawdzających podobieństwo/identyczność korespondujących ze sobą elementów obu tekstów docelowych, końcowa ocena zasadności domniemania winy/niewinności tłumacza o dokonanie plagiatu pozostanie dyskusyjna. 


\section{Źródła}

Duma i uprzedzenie, tłum. A. Przedpełska-Trzeciakowska, Prószyński i S-ka, Warszawa 2002.

Duma i uprzedzenie, tłum. M. Gawlik-Małkowska, Prószyński i S-ka, Warszawa 2004.

Hamlet, William Shakespeare, tłum. M. Słomczyński, Zielona Sowa, Kraków 1999.

Hamlet, William Shakespeare, tłum. S. Barańczak, W drodze, Poznań 1990.

Hamlet, William Shakespeare, Cambridge University Press., Cambridge 1934.

Pride and Prejudice, Jane Austin, Collins, London and Glasgow 1813.

\section{Literatura}

Austin, J.L., 1962, How to Do Things with Words, Oxford.

Barta, J., Czajkowska-Dąbrowska, M., Ćwiąkalski, Z., Markiewicz, R., Traple, E., 1995, Komentarz do ustawy o prawie autorskim i prawach pokrewnych, Warszawa.

Błeszyński, J., Staszków, M., 1983, Prawo autorskie i wynalazcze, Warszawa.

Bowden, D., 1996, „Stolen Voices: Plagiarism and Authentic Voice”, [w:] Composition Studies/Freshman English News, s. 24.1-2.

Chambers, J.K., 1995, Sociolinguistic Theory, Cambridge.

Duszak, A., 1998, Tekst, dyskurs, komunikacja międzykulturowa, Warszawa.

Eco, U., 1984, The Role of the Reader. Exploration in the Semiotics of Texts, Bloomington.

Gadamer, H-G., 1966, Mensch und Sprache. Kleine Schriften: Tybinga. Słowo, rozum, dzieje, Michalski, K. (red.), tłum. K. Michalski (2001), Warszawa, s. 47-65.

Garcarz, M., 2007, Przekład slangu w filmie. Telewizyjne przekłady filmów amerykańskich na język polski, Kraków.

Giles, D., 1986, „A Structural Analysis of the Police Story”, [w:] American Television Genres, Kaminsky, S., Mahn, J.H. (red.), Chicago, s. 67-84.

Gutt, E.A., 2000, Translation and Relevance: Cognition and Context, Manchester-Boston.

Haynes-Burton, C., 1995, „Intellectual Property in Writing Centers: Retro Texts and Positive Plagiarism", [w:] Writing Center Perspectives, Stay, B.L. Murphy, Ch., Hobson, E.H. (red.), National Writing Centers Association, s. 84-93. 
Hellonger, M., 2004, Gender Across Languages: the Linguistic Representation of Women and Men, Amsterdam.

Howard, R.M., 1993, „A Plagiarism Pentimento”, [w:] Journal of Teaching Writing 11.3, s. 233-46.

Howard, J., 1968, The Fragmentation of Literary Theory, Oxford.

Mallon, T., 1989, Stolen Words: Forays into the Origins and Ravages of Plagiarism, New York.

Mocarz, M., 2002, „Jednostka tłumaczenia - koncepcja opisu i sposoby jej wyrażania", [w:] II Warsztaty Translatorskie-Workshop on Translation, Sokalowski, R., Duda, H. (red.), Lublin, Ottawa, s. 121-140.

Pisarska, A., Tomaszkiewicz, T., 1996, Współczesne tendencje przekładoznawcze, Poznań.

Porter, J.E., 1993, „Selected Bibliography: The Concept of 'Author' in Rhetoric/Composition and Literary Theory", [w:] Rhetoric Society Quarterly, 23, s. 71-5.

Posner, R.A., 2002, „On Plagiarism”, [w:] The Atlantic Monthly, s. 20-27.

Sapir, E., 1921, Language: An Introduction to the Study of Speech, New York.

Schleiermacher, F., 1813, „Über die verschiedenen Methoden des Übersetzens", [w:] (1973) Das Problem des Übersetzens, Störig, H-J. (red.), Darmstadt, s. 38-70.

Scollon, R., 1995, „Plagiarism and Ideology: Identity in Intercultural Discourse", [w:] Language in Society, 24.1, s. 1-28.

Sperber, D., Wilson, D., [1986] 1995, Relevance: Communication and Cognition, Oxford.

Tabakowska, E., 1993, Cognitive Linguistics and Poetics of Translation, tłum. A. Pokojska: Językoznawstwo kognitywne a poetyka przekładu (2001), Kraków.

Tenesini, A., 1999, An Introduction to Feminism, Maden.

Venuti, L., 1995, The Translator's Invisibility: A History of Translation, London-New York. 


\section{The issue of plagiarism in literary translations: few words on the translator's presumption of guilt/innocence}

\section{Summary}

Translation as an act of interlinguistic communication plays a crucial role in bridging two cultures close enough to make the members of one speech community "feel" a hypothetically foreign culture by experiencing it through language they originally mastered. This paper demonstrates the complementary nature of macro-level quantitative communication studies and micro-elementary analysis of translation as a process of meaning negotiation in terms of our natural human tendency to express thoughts and intentions according to the same inborn cognitive mechanism of language expression. Here, I consider the issue of translation plagiarism, its legal definition in the copyright treaty, the scope of copyright protection as well as the difference between committing an intentional theft of intellectual creations, i.e., plagiarism and publishing another translation of the same original.

In recent years, researchers in translation studies have paid increasing attention to the socio-cultural context of language usage in terms of intercultural communication as such. Studies have drawn from a variety of cognitive frameworks to examine the direct influence of language economization on a successful and complete information transfer from culture A into culture B. In its theoretical section, the paper provides the reader with an assessment of an intercultural communication theory based on the assumption that members of the same speech community (sharing common 'communication consciousness') apply identical types of language mechanisms, which effects in creating similar grammatical or stylistic constructions. What this paper sets out to do in the practical section is to collect some data from the vast literary translations (from English to Polish) which will exemplify the problem of promoting next translation of a well known original.

Specifically, I examined two various isosemiotic translations of two literary texts (Hamlet and Pride and Prejudice). Then, I compared translations of two selected sections to indicate those that might have been hypothetically plagiarized, and revealed that all theoretical arguments about the possible copyright infringement in literary translations are groundless. Authors of two different translations share the same culturally oriented compléments cognitifs. This knowledge allows them to express the contents of the original in their mother language with the application of the same or similar language constructions. Of course, none of the analyzed works carries the stigma of plagiarism.

I end up the paper by considering the implications of this approach for future research on the presumption of plagiarism which I understand as an intentional repeating of large units of one translation into another. There is hardly a term that raises more vivid discussions among translation theoreticians than plagiarism, yet it is more difficult to define its limits. 